\title{
Reduced selenium in asthmatic subjects in New Zealand
}

Amber Flatt, Neil Pearce, Christine D Thomson, Malcolm R Sears, Marion F Robinson, Richard Beasley

\begin{abstract}
Selenium is an essential component of glutathione peroxidase, an enzyme that helps protect cells against oxidation damage and modulates the lipoxygenase pathway of arachidonic acid metabolism. Low selenium concentrations might therefore influence the inflammatory process in asthma by reducing the activity of glutathione peroxidase. Whole blood and plasma selenium concentrations and glutathione peroxidase activity have been measured in 56 asthmatic patients and 59 non-asthmatic control subjects in New Zealand, a country with a low dietary selenium intake and a high prevalence of asthma. When compared with control subjects the asthmatic patients had lower values for whole blood selenium concentrations $(-4 \cdot 9,95 \%$ confidence interval -10.2 to $0.4 \mathrm{ng} / \mathrm{ml}$ ) and glutathione peroxidase activity $(-3 \cdot 3$, $95 \% \mathrm{CI}-5.8$ to -0.8 units $/ \mathrm{g} \mathrm{Hb})$. There was a 1.9 and 5.8 fold increased risk of asthma in subjects with the lowest range of whole blood selenium concentration and glutathione peroxidase activity respectively (95\% CI 0.6 to 5.6 and 1.6 to $21 \cdot 2)$. Levels were lower in patients and control subjects without an atopic predisposition, but were not affected by prednisone use. Similar differences between the asthmatic and control subjects were not observed for selenium concentration or glutathione peroxidase activity measured in plasma, which reflects short term rather than long term selenium content. These findings are consistent with the hypothesis that low selenium concentrations may have a role in the pathogenesis of asthma in New Zealand.
\end{abstract}

Since the discovery that the essential trace element selenium is an integral part of the enzyme glutathione peroxidase ${ }^{1}$ and that reduced dietary intake of selenium results in reduced glutathione peroxidase activity, ${ }^{2}$ there has been considerable interest in the question of whether selenium deficiency might have a role in certain disease processes. Certainly there is convincing evidence that selenium deficiency may predispose to disease in animals, with liver necrosis, muscular dystrophy, cardiomyopathy, pancreatic lesions, and infertility having been induced in different animal species when fed a selenium deficient diet. ${ }^{3}$ In humans the identification of a definite

pathological condition attributable to low selenium intake has been more difficult, though it has been implicated in several diseases, including Keshan's disease (cardiomyopathy), ${ }^{4}$ Kashin-Beck disease (osteoarthropathy), ${ }^{5}$ myositis, ${ }^{6}$ cancer, ${ }^{7}$ and heart disease. ${ }^{8}$

There is now evidence to suggest that lower than normal selenium concentrations may exist in patients with asthma. Malmgren and coworkers initially reported lowered whole blood glutathione peroxidase activity in patients with asthma who had food and aspirin intolerance. ${ }^{9}$ More recently a British study found a lower concentration of selenium in red blood cells and plasma in asthmatic patients than in normal subjects. ${ }^{10}$ With the lower ranges of selenium concentrations the probability that asthma was present was increased up to five fold. These findings are of interest because the population of New Zealand has low selenium concentrations and glutathione peroxidase activities $^{1112}$ and a high prevalence of asthma. ${ }^{13}$ The low blood concentrations of selenium in the New Zealand population reflect a low dietary intake of selenium, usually less than $30 \mu \mathrm{g}$ per day, which is often as low as that reported in the Keshan's disease region. ${ }^{14}$ The low selenium concentrations in the plant and animal food in turn reflect the very low selenium content of the soil, particularly in the cereal growing areas of Canterbury and Otago, where levels are less than $0.01 \mu \mathrm{g}$ selenium $/ \mathrm{g} .{ }^{15}$

There are two major mechanisms whereby selenium deficiency associated with lowered glutathione peroxidase activity may be relevant to the pathogenesis of asthma. The first is that it results in reduced protection from oxidative damage caused by free radicals and hydroperoxides released during the inflammatory process, ${ }^{1617}$ leading to worsening airways inflammation in asthma. The second is by modulation of the lipoxygenase pathway of arachidonic acid metabolism. ${ }^{16-18}$ In particular, reduced glutathione peroxidase activity decreases the reduction of 12-hydroperoxyeicosatetraenoic acid (12-HPETE), which stimulates the synthesis and release of the potent inflammatory mediator leukotrine $\mathrm{B}_{4}{ }^{19}$

The aim of the present study was to assess the selenium concentrations of patients with asthma in New Zealand. We have measured the selenium concentration and glutathione peroxidase activity in whole blood and plasma in asthmatic patients, and compared the values with those from non-asthmatic control subjects. The study was undertaken in the Otago area because it is self sufficient in cereal and meat products. As a result, selenium concenMedicine Department of of Medicine, PO Box 7343, Wellington South, New Zealand.

Accepted 26 October 1989 
trations in Otago are less likely to be influenced by the intermittent importation of Australian wheat, which has a 10 fold greater selenium content and may result in measurable increases in selenium concentration. ${ }^{20}$

\section{Methods \\ SUBJECTS}

Patients We studied 63 asthmatic subjects enrolled from an outpatient chest clinic in Dunedin and a general practice in Tapanui, Otago. All asthmatic subjects completed a questionnaire that included details of their alcohol consumption, smoking habits, diet, medical history, and medication. Non-specific airway responsiveness was assessed by methacholine inhalation challenge by the method of Sears $e t a l^{21}$ to determine the provoking concentration of methacholine that induced a $20 \%$ fall in $\mathrm{FEV}_{1}\left(\mathrm{PC}_{20} \mathrm{FEV}_{1}\right)$. Atopy was assessed by skinprick testing with common allergens. After the exclusion of three subjects who had taken selenium supplements within the last two years and of four whose methacholine $\mathrm{PC}_{20} \mathrm{FEV}_{1}$ was greater than $8 \mathrm{mg} / \mathrm{ml}$ there were 56 asthmatic subjects, 32 women and 24 men, aged 15-62 (mean 39) years, who were included in the analysis. The baseline $\mathrm{FEV}_{1}$ was $73 \%$ predicted, and geometric mean methacholine $\mathrm{PC}_{20} \mathrm{FEV}_{1} 0.3 \mathrm{mg} / \mathrm{ml}$. Of the 56 subjects, 55 inhaled beta adrenoceptor agonists for symptomatic relief, 53 inhaled corticosteroids, 31 took oral theophylline preparations and 22 oral beta agonists, and 11 inhaled sodium cromoglycate. There were 17 patients taking continuous oral corticosteroids, a further 26 who had received a course within the last 12 months, and 13 who reported that they had not received oral corticosteroids in the last 12 months. Twelve patients said that they were current cigarette smokers and 40 that they drank alcohol; no one was on an exclusion diet.

Control subjects Sixty four volunteers were selected from a general medical outpatient and blood donor population and from the families of the asthmatic subjects in an attempt to obtain a control group similar in age and sex to the asthmatic subjects. All the control subjects completed the same questionnaire, and underwent bronchial challenge and skinprick testing. After exclusion of one who had taken selenium supplements within the last two years and four who reported a past history of asthma (no one had a $\mathrm{PC}_{20}$ less than $4 \mathrm{mg} / \mathrm{ml}$ ) there were 59 subjects for comparison, 33 female and 26 male, aged 18-61 (mean 37) years. No subjects had recently taken oral corticosteroids. Sixteen were current cigarette smokers and 51 drank alcohol; no one was on an exclusion diet.

\section{ASSAY METHODS}

A $10 \mathrm{ml}$ venous blood sample was collected for assay of selenium and glutathione peroxidase in whole blood and plasma. The blood was drawn into heparinised tubes and centrifuged to separate the plasma. Selenium was measured by automated fluorimetry ${ }^{22}$ and glutathione peroxidase activity assayed by a modification ${ }^{23}$ of the coupled method of Paglia and Valentine ${ }^{24}$ with $t$-butylhydroperoxide $(0.3 \mathrm{mmol} / \mathrm{l})$ as substrate and $3 \mathrm{mmol} / 1$ glutathione at $25^{\circ} \mathrm{C}$, pH $7 \cdot 3$. Protein concentration was measured by the method of Lowry et al..$^{25}$ All measurements were undertaken blind after coding of the samples.

\section{STATISTICAL ANALYSIS}

Normal probability plots ( $Q-Q$ plots) were constructed to check that the selenium concentrations and glutathione peroxidase activities were normally distributed in cases and controls. The unpaired Student's $t$ test was used for between group comparisons, and 95\% confidence intervals for the differences between means were also calculated. The assumptions of equal population variances were tested with an $\mathrm{F}$ test. ${ }^{26}$ The SAS logistic procedure was used to perform unconditional logistic regression ${ }^{27}$ to calculate the odds ratios (relative risk) of asthma according to various selenium concentrations and glutathione peroxidase activities.

The only important confounders were age and gender, and the logistic regression analyses were adjusted for these factors. Several factors, including farming, taking vitamin $\mathrm{E}$ or yeast supplements, cigarette smoking, use of the oral contraceptive pill, alcohol consumption, recent overseas travel, and atopy, were considered in the initial analysis but were found to be unrelated to whole blood selenium concentrations or glutathione peroxidase activity or to affect too few subjects to influence the overall effect.

The study was approved by the Otago Hospital Board ethical committee and all subjects gave informed, written consent.

\section{Results}

The mean whole blood and plasma selenium concentration and glutathione peroxidase activity in asthmatic patients and control subjects are shown in table 1 . There was little difference between these two groups in plasma selenium or glutathione peroxidase, but for whole blood both selenium concentrations and glutathione peroxidase activity were lower in the asthmatic than the control group. The differences in mean whole blood selenium

Table 1 Comparison of selenium concentration and glutathione peroxidase activity in whole blood and plasma in patients with asthma and control subjects

\begin{tabular}{|c|c|c|c|c|}
\hline & $\begin{array}{l}\text { Asthma cases }(n=56) \\
\text { Mean }(S E M)\end{array}$ & $\begin{array}{l}\text { Controls }(n=59) \\
\text { Mean }(S E M)\end{array}$ & Difference & $\begin{array}{l}95 \% \text { confidence } \\
\text { interval }\end{array}$ \\
\hline $\begin{array}{l}\text { Selenium }(\mathrm{ng} / \mathrm{ml}) \\
\text { Blood } \\
\text { Plasma }\end{array}$ & $\begin{array}{ll}66.4 & (1.9) \\
58.7 & (1.9)\end{array}$ & $\begin{array}{ll}71 \cdot 3 & (2 \cdot 0) \\
60 \cdot 6 & (1 \cdot 8)\end{array}$ & $\begin{array}{l}-4.9 \\
-1.9\end{array}$ & $\begin{array}{l}-10 \cdot 2 \text { to } 0.4 \\
-7 \cdot 0 \text { to } 3 \cdot 2\end{array}$ \\
\hline $\begin{array}{l}\text { Glutathione peroxidase: } \\
\text { Blood (units/g Hb) } \\
\text { Plasma (units/g protein) }\end{array}$ & $\begin{array}{cl}23.3 & (0.9) \\
3.15 & (0.08)\end{array}$ & $\begin{array}{cl}26 \cdot 6 & (0.9) \\
3.11 & (0 \cdot 10)\end{array}$ & $\begin{array}{c}-3.3 \\
0.04\end{array}$ & $\begin{array}{l}-5.8 \text { to }-0.8 \\
-0.21 \text { to } 0.29\end{array}$ \\
\hline
\end{tabular}


Table 2 Comparison of whole blood selenium concentrations and glutathione peroxidase activity in patients with asthma and control subjects according to the presence or absence of eczema, rhinitis, and atopy

\begin{tabular}{|c|c|c|c|c|c|c|c|c|}
\hline & \multicolumn{3}{|c|}{ Asthma } & \multicolumn{3}{|c|}{ Control } & \multirow[b]{2}{*}{ Difference } & \multirow{2}{*}{$\begin{array}{l}95^{\circ} \text { o confidence } \\
\text { interval }\end{array}$} \\
\hline & $n$ & Mean & (SEM) & $n$ & Mean & (SEM) & & \\
\hline $\begin{array}{c}\text { Selenium (ng/ } \\
\text { Eczema } \\
\text { No eczema } \\
\text { Rhinitis } \\
\text { No rhinitis } \\
\text { Atopic } \\
\text { Not atopic }\end{array}$ & $\begin{array}{l}17 \\
39 \\
28 \\
28 \\
42 \\
14\end{array}$ & $\begin{array}{l}68 \cdot 3 \\
65 \cdot 6 \\
66 \cdot 3 \\
66 \cdot 5 \\
66 \cdot 6 \\
65 \cdot 7\end{array}$ & $\begin{array}{l}(3 \cdot 3) \\
(2 \cdot 3) \\
(2 \cdot 2) \\
(3 \cdot 1) \\
(2 \cdot 2) \\
(3 \cdot 9)\end{array}$ & $\begin{array}{l}11 \\
48 \\
11 \\
48 \\
14 \\
45\end{array}$ & $\begin{array}{l}73 \cdot 3 \\
70 \cdot 9 \\
75.9 \\
70 \cdot 3 \\
73 \cdot 2 \\
70 \cdot 7\end{array}$ & $\begin{array}{l}(5 \cdot 3) \\
(2 \cdot 1) \\
(4 \cdot 2) \\
(2 \cdot 2) \\
(3 \cdot 9) \\
(2 \cdot 3)\end{array}$ & $\begin{array}{l}-5 \cdot 0 \\
-5 \cdot 3 \\
-9 \cdot 6 \\
-3 \cdot 8 \\
-6 \cdot 6 \\
-5 \cdot 0\end{array}$ & $\begin{array}{rr}-15 \cdot 0 \text { to } & 5 \cdot 0 \\
-11.4 \text { to } & 0 \cdot 8 \\
-18 \cdot 3 \text { to } & -0.8 \\
-11.0 \text { to } & 3 \cdot 4 \\
-15 \cdot 2 \text { to } & 2 \cdot 0 \\
-14 \cdot 1 \text { to } & 4 \cdot 1\end{array}$ \\
\hline $\begin{array}{l}\text { Glutathione p } \\
\text { Eczema } \\
\text { No eczema } \\
\text { Rhinitis } \\
\text { No rhinitis } \\
\text { Atopic } \\
\text { Not atopic }\end{array}$ & $\begin{array}{c}\text { e (un } \\
17 \\
39 \\
28 \\
28 \\
42 \\
14\end{array}$ & $\begin{array}{c}\text { ts } / \text { g Hb) } \\
25.0 \\
22.5 \\
23.2 \\
23.3 \\
23.9 \\
21.3\end{array}$ & $\begin{array}{l}(1 \cdot 9) \\
(1 \cdot 1) \\
(1 \cdot 2) \\
(1 \cdot 5) \\
(1 \cdot 2) \\
(1 \cdot 4)\end{array}$ & $\begin{array}{l}11 \\
48 \\
11 \\
48 \\
14 \\
45\end{array}$ & $\begin{array}{l}28 \cdot 4 \\
26 \cdot 2 \\
28 \cdot 0 \\
26 \cdot 3 \\
27 \cdot 1 \\
26 \cdot 5\end{array}$ & $\begin{array}{l}(1 \cdot 7) \\
(1 \cdot 1) \\
(3 \cdot 0) \\
(0.8) \\
(2 \cdot 8) \\
(0 \cdot 8)\end{array}$ & $\begin{array}{l}-3 \cdot 4 \\
-3 \cdot 7 \\
-4 \cdot 8 \\
-3 \cdot 0 \\
-3 \cdot 2 \\
-5 \cdot 2\end{array}$ & $\begin{array}{l}-8.8 \text { to } 2.0 \\
-6.6 \text { to }-0.8 \\
-10.0 \text { to } 0.4 \\
=6.1 \text { to } 0.1 \\
=8.2 \text { to } 1.8 \\
-8.4 \text { to }-2.0\end{array}$ \\
\hline
\end{tabular}

concentrations were similar in men (difference $-4 \cdot 3$ ) and in women (difference $-5 \cdot 5)$. The differences in whole blood glutathione peroxidase activities were also similar in men (difference -3.5) and women (difference $-3 \cdot 2)$.

In both the asthmatic and control groups the mean whole blood selenium concentrations and glutathione peroxidase activities were generally higher in those who reported having eczema or rhinitis or had positive responses to skinprick tests (table 2). The differences between the asthmatic and control groups, however, were consistent and similar in each of these subgroups.

The possibility of an effect due to beta agonists was assessed by excluding the 22 asthmatic subjects taking oral beta agonists. This resulted in a small reduction in the difference in whole blood selenium (from 4.9 to $3.9 \mathrm{ng} / \mathrm{ml}$ ) and a larger reduction for glutathione peroxidase (from 3.3 to 2.0 units $/ \mathrm{g} \mathrm{Hb}$ ).

Prednisone use was not associated with significant differences in whole blood selenium; the mean concentrations were $65.5 \mathrm{ng} / \mathrm{ml}$ in the 13 patients who had never used prednisone, $66.9 \mathrm{ng} / \mathrm{ml}$ in the 26 prescribed a short course, and $66.2 \mathrm{ng} / \mathrm{ml}$ in the 17 cases prescribed a continuous course. The corresponding mean activities of whole blood glutathione peroxidase were $24 \cdot 8,23 \cdot 1$, and $22 \cdot 5$ units/g $\mathrm{Hb}$.

Table 3 shows that the trend for the risk of

Table 3 Relative risk of asthma according to whole blood and plasma selenium concentration and glutathione peroxidase activity

\begin{tabular}{|c|c|c|c|c|}
\hline & Asthma & Control & Odds ratio & $95 \% C I$ \\
\hline $\begin{array}{l}\text { Whole blood } \\
\geqslant 80 \\
70-79 \\
60-69 \\
<60\end{array}$ & $\begin{array}{l}\text { m concen } \\
11 \\
9 \\
18 \\
18\end{array}$ & $\begin{array}{l}3 / \mathrm{ml}): \\
14 \\
14 \\
19 \\
12\end{array}$ & $\begin{array}{l}1 \cdot 0 \\
0 \cdot 8 \\
1 \cdot 4 \\
1.9\end{array}$ & $\begin{array}{l}-\overline{0.3} \text { to } 2.6 \\
0.5 \text { to } 3.9 \\
0.6 \text { to } 5.6\end{array}$ \\
\hline $\begin{array}{c}\text { Plasma selen } \\
\geqslant 70 \\
60-69 \\
50-59 \\
<50\end{array}$ & $\begin{array}{l}\text { centratior } \\
8 \\
16 \\
20 \\
12\end{array}$ & $\begin{array}{l}14 \\
14 \\
18 \\
13\end{array}$ & $\begin{array}{l}1 \cdot 0 \\
2 \cdot 1 \\
2 \cdot 2 \\
1 \cdot 7\end{array}$ & $\begin{array}{l}\overline{0.7} \text { to } 6.7 \\
0.7 \text { to } 6.5 \\
0.5 \text { to } 5.5\end{array}$ \\
\hline $\begin{array}{c}\text { Whole blood } \\
\geqslant 30 \\
25-29 \\
20-24 \\
<20\end{array}$ & $\begin{array}{c}\text { ione pero } \\
7 \\
14 \\
15 \\
20\end{array}$ & $\begin{array}{l}\text { vity (units } \\
13 \\
19 \\
20 \\
7\end{array}$ & $\begin{array}{l}1 \cdot 0 \\
1 \cdot 4 \\
1 \cdot 6 \\
5 \cdot 8\end{array}$ & $\begin{array}{l}-\overline{0.4} \text { to } 4.5 \\
0.5 \text { to } 5.2 \\
1.6 \text { to } 21.2\end{array}$ \\
\hline $\begin{array}{c}\text { Plasma gluta } \\
\geqslant 3.5 \\
3.0-3.4 \\
2.5-2.9 \\
<2.5\end{array}$ & $\begin{array}{l}\text { eroxidase } \\
14 \\
18 \\
17 \\
7\end{array}$ & $\begin{array}{l}\text { units/g pro } \\
18 \\
14 \\
17 \\
10\end{array}$ & $\begin{array}{l}1.0 \\
1.6 \\
1.3 \\
0.9\end{array}$ & $\begin{array}{l}-\overline{0.6} \text { to } 4.4 \\
0.5 \text { to } 3.5 \\
0.3 \text { to } 2.9\end{array}$ \\
\hline
\end{tabular}

asthma to increase with decreasing concentrations of whole blood selenium was relatively weak ( $p=0.35$ ), but a whole blood selenium concentration of less than $60 \mathrm{ng} / \mathrm{ml}$ was associated with a 1.9 fold risk of asthma $(95 \% \mathrm{CI}$ 0.6 to 5.6 ) by comparison with the baseline concentration of over $80 \mathrm{ng} / \mathrm{ml}$. Similarly, there was a weak overall trend for the risk of asthma to increase with decreasing whole blood glutathione peroxidase $(p=0.23)$, though whole blood glutathione peroxidase activity of less than 20 units/g Hb was associated with a nearly sixfold risk of asthma $(95 \%$ CI 1.6 to 21.2). When whole blood selenium and whole blood glutathione peroxidase were entered simultaneously into the model the estimates were unstable; but the increased risk at low concentrations of whole blood selenium disappeared (odds ratio $0.7,95 \%$ CI 0.2 to $2 \cdot 8$ ), whereas the increased risk at low levels of glutathione peroxidase was maintained (odds ratio $7 \cdot 0,95 \%$ CI $1 \cdot 5$ to $33 \cdot 1$ ).

\section{Discussion}

In this study we have shown that patients with asthma have lower whole blood selenium concentrations and glutathione peroxidase activity than a non-asthmatic control population. Subjects in the lowest ranges of whole blood selenium concentration had a twofold relative risk of asthma, and subjects in the lowest range of glutathione peroxidase activity had a sixfold relative risk of asthma. The increased risk of asthma was virtually confined to these groups and the risk was only moderately increased in subjects with intermediate levels of whole blood selenium and glutathione peroxidase. These changes were not accompanied by a reduction in plasma levels, which in contrast to whole blood levels reflect short term changes in selenium concentration. ${ }^{12}$

Reduced glutathione peroxidase activity in patients with asthma may lead to a worsening of the airways inflammation that is a characteristic feature of this disorder. ${ }^{28} 29$ The enzyme glutathione peroxidase protects cells against oxygen radicals such as superoxide and hydrogen peroxide, which have the potential to damage cell membranes through lipid peroxidation. ${ }^{30}$ Lowered glutathione peroxidase activity may thus lead to reduced protection against the oxidation damage caused by these 
oxygen radicals released during the inflammatory process. Another possible mechanism whereby reduced glutathione peroxidase activity may be relevant to the inflammatory process in asthma relates to its putative role as a regulator of the lipoxygenase pathway of arachidonic and metabolism. ${ }^{16-18}$

In addition to the effects that might result from reduced glutathione peroxidase activity, a lowered selenium concentration might have relevant effects independent of this enzyme activity. Selenium can be incorporated in several distinct proteins, and although biological activity has not been identified for all of these proteins specific immunological defects can occur with selenium deficiency. In polymorphonuclear leucocytes selenium is necessary for all metabolic steps during phagocytosis, ${ }^{31}$ including postphagocytic cytotoxicity. ${ }^{32}$ Selenium deficiency has also been shown to suppress antibody synthesis ${ }^{33}$ and lead to reduced $T$ cell function. ${ }^{34}$

In contrast to the values for whole blood, there was little difference in plasma selenium concentrations or glutathione peroxidase activity between the asthmatic and control groups. This may be because plasma selenium reflects short term rather than long term selenium content and may therefore be more readily influenced by recent changes in dietary intake. ${ }^{12}$ Whole blood selenium and glutathione peroxidase activity give a longer term index of selenium, ${ }^{35}$ although it is uncertain what relation these indices have to whole body selenium or whether it is the best indicator for biological activities. The activity of glutathione peroxidase is relatively high in human peripheral polymorphonuclear leucocytes ${ }^{36}$ and platelets ${ }^{37}$ and measurement of glutathione peroxidase activity in these may give a better indication of the relevance of reduced selenium to an inflammatory disorder such as asthma. Preliminary unpublished results from our laboratory suggest that the glutathione peroxidase activity per cell may be as much as 15-20 times greater in leucocytes than in erythrocytes.

The possibility that the enteropathy associated with eczema may contribute to the lower selenium concentrations in patients with asthma and eczema has been raised, ${ }^{10}$ because reduced selenium has been observed in patients with eczema ${ }^{38}$ and patients with both asthma and eczema have been found to have a tendency towards lower selenium concentrations than patients with asthma alone. ${ }^{10}$ In contrast, we found that whole blood selenium concentrations and glutathione peroxidase activities were slightly higher in subjects with eczema in both the asthma and the control group. A similar trend was noted when subjects were classified on the basis of atopy (positive skin test responses) or a history of rhinitis.

Another possible explanation for our findings is that they are due to the effects of beta agonists taken by the asthmatic subjects. This is partially supported by our observation that the differences between the asthmatic and the control group were reduced, but not eliminated, when those patients taking oral beta agonists were excluded. An alternative explan- ation (if the association is causal) is that those taking oral beta agonists have more severe asthma. It appears unlikely that our findings can be attributed to inhaled beta agonists, because these were withheld for at least six hours before blood sampling. Although beta agonist treatment causes a fall in serum potassium, calcium, and magnesium and plasma phosphate concentrations, ${ }^{39}$ it is unknown whether they cause a similar effect with selenium or whether such an effect would alter glutathione peroxidase activity. Further work investigating the effect of beta agonists on selenium concentrations and glutathione peroxidase activity is required.

The effect of oral corticosteroids on selenium has also not been formally investigated. Although most of our asthmatic subjects had received oral corticosteroids either daily or as a short course within the previous year, their selenium and glutathione peroxidase levels were not very different from those who had not received these agents, which is consistent with previous observations. ${ }^{10}$ Finally, the effect of asthma itself in lowering selenium concentrations cannot be excluded as a partial or total explanation of our observations.

Although smoking, alcohol consumption and the use of the oral contraceptive pill have been reported to reduce selenium concentrations, ${ }^{40}$ this has not always been found. ${ }^{1041}$ In the present study similar proportions of the two groups had these characteristics, and we did not observe a relation between any of these characteristics and selenium concentrations.

In conclusion, we have shown that blood selenium concentrations are low in patients with asthma in New Zealand, and that this is associated with reduced glutathione peroxidase activity. We observed a sixfold increased risk of asthma among subjects with low glutathione peroxidase activity. Although there are several possible explanations for these findings, our results are consistent with the hypothesis that lowered selenium concentrations and reduced glutathione peroxidase activity may contribute to the pathogenesis of asthma in New Zealand.

We thank Mr Peter Huemmer and Ms Trudy Milne for their technical assistance with the selenium analyses and glutathione peroxidase assays; Dr Peter Snow for allowing us access to his patients; Miss Erin Flannery for assistance with pulmonary function studies, and $\mathrm{Mrs} \mathrm{H}$ Bark and Mrs M Stretch for secretarial assistance. This work was supported by the Medical Research Council of New Zealand.

1 Rotruck JT, Pope AL, Ganther HE, Swanson AB, Hafeman DG, Hoekstra WG. Selenium: biochemical role as a component of glutathione peroxidase. Science 1973;179: 588-90.

2 Hafeman DG, Sunde RA, Hoekstra WG. Effect of dietary selenium on erythrocyte and liver glutathione peroxidase selenium on erythrocyte and liver
in the rat. $J$ Nutr $1974 ; 104: 580-7$.

3 Burk RF, Diplock AI, Gopalan HNB, et al. Effects of selenium on animals. In: Selenium. Environmental health criteria. Geneva: World Health Organisation, 1987:

4 Keshan Disease Research Group. Epidemiologic studies on the etiologic relationship of selenium and Keshan disease. Chin Med J 1979;92:477-82.

5 Sokoloff L. Endemic forms of osteoarthritis. Clin Rheum Dis 
1985;11:187-202.

6 Van Rij AM, Thomson CD, McKenzie JM, Robinson MF. Selenium deficiency in total parenteral nutrition. $\mathrm{Am} J$ Clin Nutr 1979;32:2076-85.

7 Shamberger RJ, Frost DV. Possible protective effect of selenium against human cancer. Can Med Assoc J 1969; 100:682.

8 Salonen JT, Alfthan G, Huttunen JK, Pikkarainen J, Puska $P$. Association between cardiovascular death and myocar-
dial infarction and serum selenium in a watched-pair longitudinal study. Lancet 1982;ii:175-9.

9 Malmgren R, Unge G, Zetterstrom O, Theovell H, de Wahl $\mathrm{K}$. Lowered glutathione peroxidase activity in asthmatic patients with food and aspirin intolerance. Allergy 1986; 41:43-5.

10 Stone J, Hinks LJ, Beasley R, Holgate ST, Clayton BE. Selenium status of patients with asthma. Clin $\mathrm{Sci}$ 1989;77:495-500.

11 Griffiths NM, Thomson CD. Selenium in whole blood in New Zealand residents. NZ Med J 1974;80:199-202.

12 Rea HM, Thomson CD, Campbell DR, Robinson MF. Relation between erythrocyte selenium concentrations and glutathione peroxidase (EC 1.11.1.9) activities of New Zealand residents and visitors to New Zealand. Br J Nutr 1979;42:201-8.

13 Jones DT, Sears MR, Holdaway MD, et al. Childhood asthma in New Zealand. Br J Dis Chest 1987;81:332-40.

$14 \mathrm{Ge} \mathrm{K}$, Xue A, Bai J, Wang S. Keshan disease-an endemic cardiomyopathy in China. Virchows Arch (Pathol Anat) 1983;401:1-15.

15 Robinson MF. Selenium and man. NZ Med J 1985;98: 278-80.

16 Flohe L, Günzler A, Loschen G. The glutathione peroxidase reaction: A key to understand the selenium requirement of mammals. In: Kharasch $\mathrm{N}$, ed. Trace metals in health and disease. New York: Raven Press, 1979:263-85.

17 Burk RF. Biological activity of selenium. Ann Rev Nutr 1983;3:53-70.

18 Van Rij AM, Wade C, Kirk I, Thomson CD, Robinson MF. Altered platelet lipoxygenase activity in patients with low selenium. Clin Sci 1987;73:525-9.

19 Maclouf J, de Laclos BF, Borgeat P. Stimulation of leukotriene biosynthesis in human blood leukocytes by plateletderived 12-hydroperoxyeicosatetraenoic acid. Proc Nat Acad Sci USA 1982;79:6042-6.

20 Robinson MF, Thomson CD. Effect of a shipment of highselenium wheat on selenium status of Otago (NZ) residents. In: Hurley L, Keen C, Lonnerdal B, Recker R, eds. Trace elements in man and animals. New York: Plenum Press, 1988.

21 Sears MR, Jones DT, Holdaway MD, et al. Prevalence of bronchial reactivity to inhaled methacholine in New Zealand children. Thorax 1986;41:283-9.

22 Brown MW, Watkinson JH. An automated fluorimetric method for the determination of nanogram quantities of method for the determination of nanogram

23 Thomson CD, Robinson MF, Campbell DR, Rea HM. Effect of prolonged supplementation with daily supplements of selenomethionine and sodium selenite on glutathione peroxidase activity in the blood of New Zealand residents. Am J Clin Nutr 1982;36:24-31.

24 Paglia DE, Valentine WN. Studies on the quantitative and qualitative characterization of erythrocyte glutathione qualitative characterization of erythrocyte
peroxidase. J Lab Clin Med 1967;70:158-69.

25 Lowry OH, Roseborough NJ, Farr AL, Randall RJ. Protein measurement with the Folin-phenol reagent. J Biol Chem 1951;193:265-75

26 SAS Institute. SAS users guide: statistics. Cary, North Carolina: SAS Institute, 1985.

27 Harrell F. The logist procedure. In: SAS Institute. SAS supplemental library user's guide. Cary, North Carolina: SAS Institute, 1986:269-93.

28 Dunnill MS. The pathology of asthma, with special reference to changes in the bronchial mucosa. J Clin Pathol 1960;13:27-33.

29 Beasley R, Roche WR, Roberts JA, Holgate ST. Cellular events in the bronchi in mild asthma and after bronchial provocation. Am Rev Respir Dis 1989;139:806-17.

30 Halliwell B, Gutteridge JC. The importance of free radicals and catalytic metal ions in human disease. Mol Aspects Med 1985;8:89-193.

31 Dimitrov NV, Ullrey DE, Primack S, Ku PK, Miller ER, Meyer C. Selenium as a metabolic modulator of phagocytosis [abstract]. In: Coombs CFJ, Spallholz, eds. Proceedings: third international symposium on selenium in biology and medicine, Beijing, 1984. Westport, Connecticut: Avi, 1984:16.

32 Bryant RW, Bailey JM. Altered lipoxygenase metabolism and decreased glutathione peroxidase activity in platelets from selenium deficient rats. Biochem Biophys Res Comm 1980;92:268-76.

33 Nockels CF. Protective effects of supplemental vitamin E against infection. Fed Proc 1979;38:2134-8.

34 Gooch G, Spallholz JE. Some effects of selenium on the Bcell and T-cell compartments of the immune system [abstract]. In: Coombs CFJ, Spallholz, eds. Proceedings: third international symposium on selenium in biology and medicine, Beijing, 1984. Westport, Connecticut: Avi, 1984:131.

35 Thomson CD, Robinson MF. Selenium in health and disease with emphasis on those aspects peculiar to New Zealand. Am J Clin Nutr 1980;33:303-23.

36 Bracci R, Calabri G, Bettini F, Princi P. Glutathione peroxidase in human leucocytes. Clin Chem Acta 1970; 29:345-48.

37 Karpatkin S, Weiss HJ. Deficiency of glutathione peroxidase associated with high levels of reduced glutathione in Glanzmann's thrombasthenia. $N$ Engl J Med 1972;217: 1062-6.

38 Hinks LJ, Young S, Clayton BE. Trace element status in eczema and psoriasis. Clin Exp Derm 1987;12:93-7.

39 Smith RS, Kendall MJ. Metabolic responses to beta stimulants. J R Coll Physicians London 1984;18:190-4.

40 Lloyd B, Lloyd RS, Clayton BE. Effect of smoking, alcohol and other factors on the selenium status of a healthy population. J Epidem Community Health 1983;27:213-7.

41 Kay RG, Knight GS. Blood selenium values in an adul Auckland population group. NZ Med J 1979;90:11-3. 